\title{
Freedom of Speech and Commercial Solicitation
}

\author{
Aaron S. Resnik*
}

$\Gamma_{\mathrm{HE}}$ ambiguity and confusion that have existed regarding the extent of protection accorded by the constitutional guarantee of freedom of speech $^{1}$ to utterances concerning commercial transactions have received some clarification in recent decisions by the United States Supreme Court, ${ }^{2}$ the Supreme Court of California ${ }^{3}$ and the District Court of Appeal of California. ${ }^{4}$ The questions that remain unanswered by these cases are many and confounding; however the following generalizations can safely be drawn from these decisions:

1. The United States Supreme Court, Justice Roberts writing a unanimous opimion in Valentine v. Chrestensen ${ }^{5}$ has held that the constitutional guarantee of freedom of speech does not restrain a state or municipality from regulating the dissemination of purely commercial advertising on the public streets or sidewalks.

2. The California Supreme Court in McKay Jewelers v. Bowron ${ }^{8}$ has held that the guarantee of freedom of speech does protect purely commercial utterances when made from the doorways and entrances of a business establishment. The court has also stated that such utterances would be protected even if made on the public sidewalks. However, this unfortunate dictum is contrary to the express holding of the Valentine case.

3. The District Court of Appeal of California in Pittsford v. Los Angeles, ${ }^{7}$ more closely approximating the decision of the United States Supreme Court, has stated that the doctrine of free speech

*Executive Secretary, Texas Social Welfare Association, Austin, Texas; member California Bar; A.B., Diploma in Social Work, University of Southern California, 1936; LL.B., University of California, 1939. Author of various articles in the Association Bulletin, published hy the Texas Social Welfare Association.

${ }^{1}$ This guarantee is provided for in the 1st and 14th Amendments of the Federal Constitution and in article I, section 9 of the California Constitution.

2 Valentine v. Chrestensen (April 13, 1942) 316 U. S. 52.

3 McKay Jewelers v. Bowron (Feb. 26, 1942) 19 Cal. (2d) 595, 122 P. (2d) 543.

* Pittsford v. Los Angeles (Feb. 17, 1942) 50 A. C. A. 24, 122 P. (2d) 535.

5Supra note 2.

G Supra note 3.

7 Supra note 4. 
does not protect purely commercial activity on the streets or sidewalks; and, further, it announces what appears to be the soundest approach to the determination of the validity of ordinances regulating commercial activities on the streets by saying, "In the final analysis the problem ... should be approached from that standpoint [a determination of the validity of the ordinance as a regulatory measure under the due process clause of the 14th Amendment as it defines the police power of a state or municipality] rather than from any consideration of the principles of freedom of speech and of the press, which, as already pointed out, are not material to the question, nor particularly relevant."8

The importance of these cases lies not in the fact that they have settled the limits of freedom of speech in relation to commercial transactions (for they have not), but rather in that they are some of the first direct and authoritative pronouncements on the whole doctrine of freedom of speech and its relation to commercial solicitation..$^{9}$

The facts in the Valentine case ${ }^{10}$ briefly were these: The respondent sought to distribute a circular in the City of New York, soliciting visitors to view his submarine. The first draft of his handbill was purely commercial in nature and he was not permitted to distribute this by the police commissioner of New York, since there was an ordinance in that city prohibiting the distribution in the streets of commercial and business advertising matter. The respondent thereupon prepared a second handbill, one side of which was purely commercial in nature, and the other side of which was an attack on the police department of the City of New York and contained no cominercial advertising. Respondent brought suit in the federal courts seeking to enjoin the police commissioner from interfering with his distribution. The district court ${ }^{11}$ granted his injunction and the cir-

8 Ibid. at 33,122 P. (2d) at 540.

0 There was some discussion of this problem in People v. Taylor (1938) 33 Cal. App. (2d) Supp. 760, 763, 85 P. (2d) 978, 979. This was a decision of the appellate department of the superior court of San Diego County, arriving at a result contrary to the decision of the Valentine case.

Judge Yankwich in Buxbom v. Riverside (S. D. Cal. 1939) 29 Fed. Supp. 3, discusses the problem, makes the distinction between commercial and non-commercial hiterature and arrives at a result consistent with the Valentine case. The distinction is also made in San Francisco S. News Co. v. South San Francisco (C. C. A. 9th, 1934) 69 F. (2d) 879; Sieroty v. Huntington Park (1931) 111 Cal. App. 377, 295 Pac. 564; People v. St. John (1930) 108 Cal. App. Supp. 779, 288 Pac. 53.

10 Supra note 2.

11 Chrestensen v. Valentine (S. D. N. Y. 1940) 34 Fed. Supp. 596. 
cuit court of appeals ${ }^{12}$ by divided court affirmed the lower court. The United States Supreme Court in a short opinion, citing not a single authority, reversed the circuit court, holding that the guarantee of freedom of speech did not extend to commercial handbills of this type. The Court, however, leaves open the question as to where the line should be drawn between a commercial and a non-commercial leaflet. It states that in this case the protest against the police department was affixed for the sole purpose of evading the law. The Court states that in this case it did not have to decide between what is of "public interest and what is for private profit."13 The court adopts what might be termed the subjective test in determining whether matter is commercial or non-commercial; the test, as applied, requires a determination of the principal purpose for which the handbill was written and distributed. ${ }^{14}$

In McKay Jewelers v. Bowron ${ }^{15}$ the California Supreme Court went out of its way to drag in a "free speech argument". That case involved the constitutionality of the so-called "pulling in ordinance" of Los Angeles. ${ }^{16}$ The material portions of the ordinance involved in the case prohibited a merchant from using the street or sidewalk in front of his place of business or any entrance, doorway or hallway abutting thereon, for the purpose of importuning and soliciting passers-by to enter the place of business for the purpose of examining or buying his wares or merchandise. The case came before the supreme court on appeal from a judgment sustaining the defendant's general demurrer to the plaintiff's complaint, which complaint sought to enjoin the enforcement of this ordinance. The plaintiffs were merchants in Los Angeles and the gravamen of the complaint stated

12 Chrestensen v. Valentine (C. C. A. 2d, 1941) 122 F. (2d) 511.

13 Valentine v. Chrestensen, supra note 2 , at 55.

14. Ibid. The test was held workable in Note (1940) 35 Irx. L. REv. 90, 94.

15 Supra note 3.

16 Section 42.02 of the Municipal Code of the City of Los ANgetes (1936) as amended August 30, 1941. Such ordinances, enacted in City of New York; Trenton, New Jersey; Fort Worth, Texas; Detroit, Michigan; Burbank, California, seek to outlaw the practice of "pulling in". This is a vicious method of securing trade and custom, and leads to the overreaching of customers, by coaxing, importuning and sometimes even forcing window gazers and passers-by to enter one's store to purchase goods, wares or merchandise. It has not been recognized as a legitimate manner of retail selling. See Pexz, Selitivg at Retall (1926) 1. In Maxwell Street [Chicago] Cleans $U p$ (1939) 5 FreEHOLd MAGAzINE 422, it is pointed out that by the elimination of the practice of "sidewalk pulling in" and by the adoption of accepted merchandise methods, there has been an improvement in business, increased sales, and removal of the stigma that attaches to a neighborhood where such practice is indulged im. 
that they importuned passers-by while they (the merchants) were on their own private property. There was no question before the court on the pleading as to whether the ordinance was valid when applied to solicitation on the street or sidewalk.

The court's first ground of decision was that such an ordinance was not a valid exercise of the police power and could not be justified under the general welfare clause of the Federal Constitution. The court pointed out that the solicitations were done in a dignified, quiet and peaceable manner and that the ordinance was an unwarranted and unreasonable interference with a lawful business, and violated both state and federal constitutional guarantees. After disposing of the case in an acceptable manner, the court then noted an additional "worthy" argument made by appellants-that of freedom of speech. The court then stated that if the constitutional guarantee of freedom of speech permits a picket to stand in the front of a business establishment and urge patrons not to enter, then by the same token a merchant can stand in the doorway of his establishment and beckon persons to enter and solicit custom from them.

This argument of the court may be severely criticized for at least two reasons, both of which are brought out quite clearly and succintly by the district court of appeal in the Pittsford case. ${ }^{17}$

1. Freedom of speech as guaranteed by the Constitution is freedom of expression on political, sociological, religious and economic subjects.

2. Such cases as the McKay case and the Pittsford case can best be decided without reference to the doctrine of freedom of speech. There is a vast body of law that has been developed dealing with the question of peddling, soliciting and hawking, and the principles there developed should form the basis of decision.

In Pittsford v. Los Angeles ${ }^{18}$ the plaintiff sought to enjoin the enforcement of a municipal ordinance of the City of Los Angeles, which provided generally that no person should deposit or distribute among pedestrians upon any street or sidewalk any commercial advertising or handbill distributed for the purpose of advertising any merchandise, commodity, business, service or skill for hire or trade. The plaintiffs employed photographers who stood on the sidewalks taking pictures of pedestrians and simultaneously with the taking of

${ }^{17}$ Supra note 4.

18 Ibid. 
the pictures handed to the pedestrian a card offering the picture for sale. The lower court overruled the general demurrer of the defendants; but on appeal the decision was reversed, the court reasoning that the ordinance was a valid exercise of the police power of the municipality and, further, stated that it was proper to draw a distinction between the exercise of constitutional rights of free speech and free press when in connection with ordinary business activities and the exercise of the same rights when in relation to public expxressions of opinion upon political, religious, social and economic questions.

The criticisms of the $M c K a y$ case, made above, are discussed seriatim.

1. Freedom of speech as one of our fundainental liberties, has received much protection from the courts of this land, and comes as near to becoming an absolute principle as any fostered by our Constitution. ${ }^{19}$ It, however, has its limitations, limitations that of necessity inust arise to foster a sound social order..$^{20}$

The freedoin of speech that is protected is freedom of speech as envisioned by the drafters of the Constitution. ${ }^{21}$ This point is clearly made by Circuit Judge Frank, dissenting in Chrestensen v. Valentine, ${ }^{22}$

"However, the historical events which yielded the Constitutional protection of free speech and free expression do not by any means compel or even suggest the conclusion that there is an equally important constitutional right to distribute commercial handbills-for the purpose of profit-making - so imperative that the city's 'pohice power' must similarly be reduced (from prevention to punishment after the fact) when pieces of paper, devised for business purposes, may litter its streets to the injury of public health or safety.

"Such men as Thomas Paine, Joln Milton and Thomas Jefferson were not fighting for the right to peddle commercial advertising. To note that fact is not at all to decry the profit-making zeal of the

19 Chafee, Free Speech in the Undted States (1941) c. 1.

20 "The right of free speech is not an absolute right to utter freely whatever a person may please. The right has been defined as embracing liberty to discuss publicly and truthfully all matters of public concern without previous restraint or fear of subsequent punishment." Rebholz, Freedom of Speech (1940) 25 MARQ. L. REv. 23. See Davis v. Massachusetts (1897) 167 U. S. 43, 47; Gitlow v. New York (1925) 268 U. S. 652, 666; see also Minersville S. Dist. v. Gobitis (1940) 310 U. S. 586; A. F. of L. v. Swing (1941) 312 U. S. 321; Cox v. New Hampshire (1941) 312 U. S. 569; Nossaman, Free Speech in Wartime (1942) 17 CaL. ST. BAR J. 109.

21 ChafeE, op. cit. supra note 19, at 6-20; Rebholz, op. cit, supra note 20.

22 Supra note 12 , at 524. 
American businessman. I, for one, would not refer, as the majority does, to a 'commercial taint'. For, as ours is a profit economy, no business man need apologize for seeking personal gain by all legitimate means. But the constitutional limitations on legislation affecting such pursuits are not as specific and exacting as those imposed on legislation interfering with free speech. To prevent the peddling of business liandbills on the street still leaves the businessman at liberty to use other modes of advertising, as in newspapers, for instance." 23

The distinction between commercial and non-commercial utterances with reference to the protection accorded each by the guarantees of free speech and free press was pointedly made in Buxbom v. Riverside. ${ }^{24}$ It was held there that a complaint seeking to enjoin the enforcement of a city ordinance prohibiting the distribution of a commercial pamphlet to private homes without prior consent of the owner, was subject to a motion to dismiss. The court states as one of its grounds that to uphold the distribution of commercial pamphlets on the basis of freedom of press calls "... for an extension of the right of free press which is not sanctioned by precedent or by any historical considerations." 25 Another leading case in which the distinction between a commercial advertising sheet and a general newspaper, printing matters of general and public interest, was recognized in San Francisco Shopping Neres Co. v. South San Francisco. ${ }^{26}$

The only sound view that can be taken, it appears, is that the distinction between commercial and non-commercial publicity must be made in the application of the doctrines of free speech and free press if these doctrines are to be applied at all. This distinction finds basis both in historical analysis and in pragmatic application of these fundamental rights.

2. The argument that cases such as the McKay and Pittsford cases could be and should be decided without consideration of the concept of freedom of speech will have much appeal to those who hold the view that the distinction between commercial and non-commercial

23 CHAFEE, op. cit. supra note 19, at 31, writes, "The true meaning of freedom of speech seems to be this. One of the most important purposes of society and government is the discovery and spread of truth on subjects of general concern." (Italics added.) (1942) 51 Yare L. J. 798; see State v. Boloff (1931) 138 Ore. 610, 625, 7 P. (2d) $775,781$.

24. Supra note 9.

25 Ibid. at 7.

${ }^{26}$ Supra note 9; other cases making the distinction appear in note 9 also. 
enterprise is artificial or is difficult of application. ${ }^{27}$ It will have appeal not only to them but to all who realize that a vast body of law has already been developed dealing with the regulations of hawking, selling and peddling, and that the principles there announced and the rules there deduced are the proper ones to be applied in such cases. ${ }^{23}$ The doctrime of the $M c K a y$ case involves an extension of freedom of speech into fields that were not envisioned by the founders of the Republic and is in a sense a mockery of those fundamental democratic rights.

In the cases upholding the validity of the so-called "Green River" ordinances ${ }^{29}$ prohibiting solicitors from making calls at private residences in pursuit of their occupations, which ordinances are somewhat analogous to the ordinance involved in the $M c K a y$ case, the courts have reasoned that such regulations were within the inumicipal police power and did not discuss the "freedom of speech" or "freedom of religion" arguments, although support for these arguments could be found in such Supreme Court cases as Cantwell v. Connecticut. ${ }^{30}$

In light of the opinion of the Umited States Supreme Court in the Valentine case and in light of Mr. Justice Roberts' statement in the famous Handbill Cases, ${ }^{31}$

"We are not to be taken as holding that commercial soliciting and canvassing may not be subjected to such regulation as the ordinance requires." 32

it would seem that if the Supreme Court were faced with a clear-cut case of the use of commercial literature or one involving the facts

27 See Circuit Judge Clarke's majority opinion in Chrestensen v. Valentine, supra note 12, at 515. The distinction is criticized in (1940) 53 HARv. L. REv. 487; (1938) 5 U. of Cerr. L. REv. 675, 676.

283 McQuilitn, The Law of Municipal Corporations (2d. ed. 1928) § $\$ 1065$, 1120. The only cases other than the McKay case involving the constitutionality of the so-called "pulling in" ordinances arose in New York. People v. Phillips (1933) 147 Misc. 11, 263 N. Y. Supp. 158; People v. Patrick (1939) 171 Misc. 705, 14 N. Y. S. (2d) 249; Matter of Dimio (1939) 102 N. Y. L. J. 2138. In all of these cases, it was reasoned that such ordinances were a valid exercise of the police power; no mention was made of the question of free speech.

29 The ordinances gain their name from the leading case of Green River v. Fuller Brush Co. (C. C. A. 10, 1933) 65 F. (2d) 112. Green River v. Bunger (1936) 50 Wyo. 52, 58 P. (2d) 456. See also In re Hartman (1938) 25 Cal. App. (2d) 55, 76 P. (2d) 709. Contra: Jewel Tea Co. v. Geneva (1940) 137 Neb. 768, 291 N. W. 664.

30 (1940) 310 U. S. 296.

31 Schneider v. State (1939) 308 U. S. 147, 165.

32 See Cantwell v. Connecticut, supra note 30; see also Lovell v. Griffin (1938) 303 U. S. 444. 
of the $M c K a y$ case that its decision would be based not on a vague and broad extension of the "free speech" doctrine, but rather on the fundamental principles that have been developed over the years, defining the limits of municipal police power. ${ }^{33}$ Any other approach would set at naught the efforts of towns and cities against constant pressure to bring some degree of quiet, dignity, decency and orderliness back to urban life; this can be achieved only by leaving the problems of regulating hawking, selling, peddling and soliciting subject to reasonable local control. ${ }^{34}$

33 (1942) 2 BILL of RTS. REv. 222.

34 In Engle, Municipal Control of Retail in the Utrited States (1935) 24 NaT. MuN. REv. 722, it is said, "Local laws, written and passed in the common interest of retailers and consumers, serve the dual purpose of elevating the competitive level of retail trade and of assuring consumers that they can trade in a well organized and administered market." 